\title{
Evaluation of Antibacterial Activity of Plant Extracts on Antibiotic Resistant Bacteria
}

\author{
C.J. Chandekar* \\ Department of Microbiology, Science College, Congress Nagar, Nagpur-440012, India \\ *Corresponding author
}

\begin{abstract}
A B S T R A C T
Keywords

Antimicrobial activity, Plant extracts, Antibiotic resistant bacteria

\section{Article Info}

Accepted:

10 November 2018

Available Online:

10 December 2018

The antimicrobial activity of plant extracts (crude extract of leaves) were evaluated against antibiotic-resistant bacteria. Crude extracts of Acacia arabica, Aegle marmelos, Ailanthus excelsa, Alstonia scholaris, Callistemon lanceolantus, Casurina equisitifolia, Catharanthus roseus, Grevellia robusta, Kalanchoe pinnata, Moringa oleifera, Psidium guajava, Saraca indica, Tamarindus indicum, Thuja compacta and Vitex negundo were selected. The plant extracts were tested against the following microorganism: Escherichia coli NCIM 2931, Proteus vulgaris NCIM 2857, Pseudomonas aeroginosa NCIM 5029, Bacillus cereus NCIM 2155, Bacillus subtilis NCIM 2063, Bacillus megaterium NCIM 2087, Klebsiella pneumoniae MTCC 432, Proteus mirabilis MTCC 425, Salmonella typhimurium MTCC 98, Salmonella typhi MTCC 734, Staphylococcus aureus MTCC 96, and Staphylococcus epidermis MTCC 43. Bacteria which were resistant to some common antibiotics (Cephalothin, Cloxacillin, Erythromycin, Gentamicin, Methicillin, Gentifloxacin, Levofloxacin, Oleadomycin, Vancomycin), were found to be susceptible to crude extract of plants studied. Ailanthus excelsa, Casurina equisitifolia, Kalanchoe pinnata, Moringa oleifera and Tamarindus indicum showed significant antimicrobial activity against bacteria studied.
\end{abstract}

\section{Introduction}

It is now common that market is receiving new antibiotics everyday to tackle the problem of drug resistance developed by pathogenic microorganisms. All pharmaceutical companies are reserving substantial part of their annual budget for developing new medicines. Clinical history of the disease is also changing due to development of new bacterial strains. Thus patients have become victim of these new drugs which are mostly tried on trial and error basis. The patients have to bear the side effects of such antibiotics such as suppressed immunity, hypersensitive reactions, stomach upsets, etc.

Plants have been used for centuries to treat infectious diseases and are considered as an important source of new antimicrobial agents (Bereksi et al., 2018). Several works have 
been done to examine the antimicrobial effects of herbal plants extracts, including roots, stem, leaves or flowers (Cowan 1999; Kakad et al., 2015)

Plant used for traditional medicine contains wide range of substances that can be used to treat chronic and infectious diseases (Alam et al., 2009).

Various plants (referred as herbal) are important in human health care and several herbal products are being used by people for various health benefits. The world health organization (WHO) estimated that about $80 \%$ of the population living in developing countries relies almost exclusively on traditional medicine for their primary health care needs (Mukherjee 2005) therefore more work is required to investigate various properties, safety and efficiency of medicinal plants (Ellof, 1998.).

Several scientists have worked on antimicrobial activities of various medicinal plants and found that these plants are effective against the microorganisms which showed drug resistance to various antibiotics (Gislene 2000). Numbers of medicinal plants were screened for their antimicrobial activity. Many workers have studied the effect of different plant extracts on bacteria producing diseases in human being (Dulger and Gonuz, 2004).

Present study involves the screening of medicinal plants having potential antimicrobial activity against those bacteria which showed antibiotic resistance against common antibiotics.

Our study deals with the crude extracts of leaves of different medicinal plants. It is always successful to test crude extract as a tool in primary screening program than to screened pure components isolated from natural products (Kusumto and Nakabayashi, 1995).

\section{Materials and Methods}

\section{Test plants used in experiment}

The following lists the plant of interest and family: Acacia arabica, (Family Mimosoideae), Aegle marmelos (FamilyRutaceae), Ailanthus excelsa (Family Simarubiaceae), Alstonia scholaris (Family Apocynaceae), Callistemom lanceolantus (Family- Myrtaceae), Casurina equisitifolia (Family - Casuarinaceae), Catharanthus roseus (Family - Apocynaceae), Grevellia robusta (Family - Proteaceae), Kalanchoe Pinnata (Family - Crassulaceae), Moringa oleifera (Family - Morinagaceae), Psidium guajava (Family - Myrtaceae), Saraca indica (Family - Leguminosae), Tamarindus indicum (Family - Leguminosae), Thuja compacta (Family - Cupressaceae) and Vitex negundo (Family - Verbanaceae).

\section{Bacterial cultures used:}

Escherichia coli NCIM 2931, Bacillus cereus NCIM 2155, Bacillus subtilis NCIM 2063,Bacillus megaterium NCIM 2087, Proteus vulgaris NCIM 2857, Pseudomonas aeroginosa NCIM 5029, Klebsiella pneumoniea MTCC 432, Proteus mirabilis MTCC 425, Salmonella typhimurium MTCC98, Salmonella typhi MTCC734, Staphylococcus aureus MTCC 96, Staphylococcus epidermis MTCC 435.

The following antibiotics were used in the present study, Cephalothin (Ch30), Cloxacillin (Cx1), Erythromycin (E5), Gentamicin (G10), Gentifloxacin (Gf 5), Levofloxacin (Lo10), Methicillin (M5), Netilmicin sulphate (Nt30), Oleadomycin (OI15), Vancomycin (Va5).

These antibiotics were procured from HImedia Mumbai, India. 
Hi -Sensitivity test broth (M 486) and Hisensitivity test agar (M 485) were procured from Hi-media Mumbai. The media were prepared according to the instructions given.

\section{Agar cup method}

\section{Preparation of inoculum}

A loopful of culture was inoculated from the stock slant culture in $5 \mathrm{ml}$ of Hi-sensitivity test broth and broth was incubated at $35 \pm 0.50 \mathrm{C}$ in BOD incubator for 18-20 hrs.

After incubation a loopful of actively growing culture was inoculated into $10 \mathrm{ml}$ of $\mathrm{Hi}$ sensitivity broth. Broth was incubated at $35 \pm 0.50 \mathrm{C}$ for $6-8$ hours. This culture was used for the inoculation of Hi-sensitivity test agar plates.

\section{Preparation of Hi-sensitivity test agar medium}

Hi-sensitivity test agar medium was prepared as per instructions of manufacturer. Required amount of agar medium was melted and 25 $\mathrm{ml}$ of molten medium was distributed in test tubes $(25 \times 150 \mathrm{~mm})$. Medium was autoclaved at $15 \mathrm{lb}$. for $20 \mathrm{~min}$. After autoclaving, medium was maintained at $45-50^{\circ} \mathrm{C}$ in constant temperature water bath.

\section{Inoculation of medium with test organism}

A $0.5 \mathrm{ml}$ of 6-8 hours old test organism is transferred to petridish (Sterilized in oven at $180^{\circ} \mathrm{C}$ for $1 \mathrm{hr}$.) using sterile micropipette. Hisensitivity test agar medium maintained at 45$50^{\circ} \mathrm{C}$ was poured and mixed properly to ensure uniform distribution of organism with medium. Seeded plates are allowed to set at room temperature.

\section{Preparation of agar cup}

$10 \mathrm{~mm}$ borer was used to cut cup in agar.
Four cups per plate at four equidistant corners were made.

A $100 \mu \mathrm{l}$ crude extract was transferred by micropipette per well. Plates were immediately kept at $4^{0} \mathrm{C}$ in refrigerator for 1 hr. and then shifted to $35 \pm 0.5^{\circ} \mathrm{C}$ in $\mathrm{BOD}$ incubator. Zone of inhibition was measured after 24 hrs. of incubation.

\section{Preparation of crude extract}

Different plant leaves were collected from around Nagpur region in the month of August-September. Leaves were cleaned under running potable water and cut into pieces and grounded in pestle and mortar (made up of dolerite stone) till homogenized mass was obtained. Homogenized mass was squeezed in 400 mesh nylon cloth (pore size 37 micron) to obtain crude extract. Crude extract was kept in sterilized glass bottle. All crude extract were prepared fresh and used before 2 hours. Cold extracts were prepared using individual fresh plant leaves.

\section{Antibacterial susceptibility test}

Preparation of inoculum medium and inoculation of test organism were repeated as discussed. Antibiotic discs, four per plate were placed at four equidistant corners. Plates were incubated at $35 \pm 0.5^{\circ} \mathrm{C}$ and zone of inhibition were read after $24 \mathrm{hrs}$.

\section{Results and Discussion}

Total 12 bacteria were used for the present study. Susceptibility of these bacteria were tested against common antibiotics. The bacteria showed resistance to variable degree to the antibiotics i.e. Cephalothrin $\left(\mathrm{Ch}^{30}\right)$, Cloxacillin $\left(\mathrm{Cx}^{1}\right), \quad$ Erythromycin $\left(\mathrm{E}^{5}\right)$, Gentamicin $\left(\mathrm{G}^{10}\right)$, Gentifloxacin $\left(\mathrm{Gf}^{5}\right)$, Levofloxacin $\left(\mathrm{Lo}^{10}\right), \quad$ Methicillin $\left(\mathrm{M}^{5}\right)$, Netilmicin sulfate $\left(\mathrm{Nt}^{30}\right)$, Oleadomycin 
$\left(\mathrm{Ol}^{15}\right)$, Vancomycin $\left(\mathrm{Va}^{5}\right)$. The results are given in Table 1. Total 15 plants were selected for the study. The 100 microlitre of crude extracts of leaves of each plant were tested against 12 bacteria. The zones of inhibition are given in Table 2.

Table.1 Susceptibility of test organisms against antibiotics (zone in $\mathrm{mm}$ )

\begin{tabular}{|c|c|c|c|c|c|c|c|c|c|c|c|c|}
\hline Antibiotics & $\begin{array}{l}\text { EC } \\
\text { NCIM } \\
2931\end{array}$ & $\begin{array}{l}\text { ST } \\
\text { MT } \\
\text { CC } \\
734\end{array}$ & $\begin{array}{l}\text { STM } \\
\text { MTCC } \\
98\end{array}$ & $\begin{array}{l}\text { KP } \\
\text { MTCC } \\
432\end{array}$ & $\begin{array}{l}\text { PV } \\
\text { NCIM } \\
2857\end{array}$ & $\begin{array}{l}\text { PM } \\
\text { MT } \\
\text { CC } \\
425\end{array}$ & $\begin{array}{l}\mathrm{PA} \\
\mathrm{NCI} \\
\mathrm{M} \\
5029\end{array}$ & $\begin{array}{l}\text { SA } \\
\text { MT } \\
\text { CC } \\
96\end{array}$ & $\begin{array}{l}\text { SE } \\
\text { MT } \\
\text { CC } \\
435\end{array}$ & $\begin{array}{l}\text { BC } \\
\text { NCIM } \\
2155\end{array}$ & $\begin{array}{l}\text { BS } \\
\text { NCIM } \\
2063\end{array}$ & $\begin{array}{l}\text { BM } \\
\text { NCIM } \\
2087\end{array}$ \\
\hline $\begin{array}{l}\text { Cephalothin } \\
\text { (Ch30) }\end{array}$ & 10 & 17 & 19 & 14 & -- & 17 & -- & 25 & 30 & 10 & 50 & 46 \\
\hline $\begin{array}{l}\text { Cloxacillin } \\
\text { (Cx1) }\end{array}$ & -- & -- & -- & -- & -- & -- & -- & 22 & 24 & 30 & 29 & 33 \\
\hline $\begin{array}{l}\text { Erythromycin } \\
\text { (E5) }\end{array}$ & -- & -- & -- & -- & -- & -- & -- & 14 & 21 & 21 & 28 & 21 \\
\hline $\begin{array}{l}\text { Gentamicin } \\
\text { (G10) }\end{array}$ & 12 & 16 & 14 & 14 & 13 & 12 & 27 & 18 & 23 & 19 & 37 & 21 \\
\hline $\begin{array}{l}\text { Gentifloxacin } \\
\text { (Gf 5) }\end{array}$ & 22 & 23 & 19 & 15 & 26 & 18 & 37 & 21 & 24 & 18 & 48 & 50 \\
\hline $\begin{array}{l}\text { Levofloxacin } \\
\text { (Lo10) }\end{array}$ & 24 & 20 & 21 & 19 & 22 & 19 & 29 & 22 & 25 & 25 & 40 & 39 \\
\hline $\begin{array}{l}\text { Methicillin } \\
\text { (M5) }\end{array}$ & -- & -- & -- & -- & -- & -- & -- & 18 & 20 & 25 & 30 & 27 \\
\hline $\begin{array}{l}\text { Netilmicin } \\
\text { sulphate } \\
(\mathrm{Nt} 30)\end{array}$ & 18 & 21 & 17 & 12 & 16 & 11 & 26 & 15 & 23 & 22 & 34 & 37 \\
\hline $\begin{array}{l}\text { Oleadomycin } \\
\text { (OI15) }\end{array}$ & -- & -- & -- & -- & -- & -- & -- & 14 & 20 & 21 & 21 & 21 \\
\hline $\begin{array}{l}\text { Vancomycin } \\
\text { (Va5) }\end{array}$ & -- & -- & -- & -- & -- & -- & -- & 12 & 15 & 17 & 22 & 16 \\
\hline
\end{tabular}


Table.2 Antimicrobial activity of crude extract against test organisms

\begin{tabular}{|c|c|c|c|c|c|c|c|c|c|c|c|c|}
\hline Plants & $\begin{array}{l}\text { EC } \\
\text { NCIM } \\
2931\end{array}$ & $\begin{array}{l}\text { ST } \\
\text { MTCC } \\
734\end{array}$ & $\begin{array}{l}\text { STM } \\
\text { MTCC } \\
98\end{array}$ & $\begin{array}{l}\text { KP } \\
\text { MTCC } \\
432\end{array}$ & $\begin{array}{l}\text { PV } \\
\text { NCIM } \\
2857\end{array}$ & $\begin{array}{l}\text { PM } \\
\text { MTCC } \\
425\end{array}$ & $\begin{array}{l}\text { PA } \\
\text { NCIM } \\
5029\end{array}$ & $\begin{array}{l}\text { SA } \\
\text { MTCC } \\
96\end{array}$ & $\begin{array}{l}\text { SE } \\
\text { MTCC } \\
435\end{array}$ & $\begin{array}{l}\text { BC } \\
\text { NCIM } \\
2155\end{array}$ & $\begin{array}{l}\text { BS } \\
\text { NCIM } \\
2063\end{array}$ & $\begin{array}{l}\text { BM } \\
\text { NCIM } \\
2087\end{array}$ \\
\hline $\begin{array}{l}\text { Acacia } \\
\text { arabica }\end{array}$ & -- & -- & 17 & -- & 12 & 14 & -- & 20 & 16 & 23 & 14 & 13 \\
\hline $\begin{array}{l}\text { Aegle } \\
\text { marmelos }\end{array}$ & 34 & 35 & 25 & 28 & 32 & 32 & 13 & -- & -- & -- & -- & -- \\
\hline $\begin{array}{l}\text { Ailanthus } \\
\text { excelsa }\end{array}$ & 18 & 15 & 20 & 22 & 13 & 28 & 11 & 16 & -- & -- & 12 & -- \\
\hline $\begin{array}{l}\text { Alstonia } \\
\text { scholaris }\end{array}$ & 33 & -- & 23 & 28 & 23 & 25 & -- & -- & -- & -- & 18 & 15 \\
\hline $\begin{array}{l}\text { Callistemom } \\
\text { Lanceolantus }\end{array}$ & -- & -- & -- & 13 & 16 & -- & 20 & 17 & -- & 22 & 16 & 16 \\
\hline $\begin{array}{l}\text { Casurina } \\
\text { equisitifolia }\end{array}$ & 28 & -- & 22 & 27 & 22 & 30 & -- & 17 & 15 & 22 & 13 & 13 \\
\hline $\begin{array}{l}\text { Catharanthus } \\
\text { roseus }\end{array}$ & 29 & -- & 17 & 26 & 25 & 16 & -- & -- & -- & -- & 22 & 19 \\
\hline $\begin{array}{l}\text { Grevellia } \\
\text { robusta }\end{array}$ & 35 & -- & 16 & 20 & -- & 27 & 15 & -- & -- & 13 & 27 & 20 \\
\hline $\begin{array}{l}\text { Kalanchoe } \\
\text { Pinnata }\end{array}$ & 31 & 13 & 32 & 24 & 29 & 31 & 12 & -- & -- & 13 & 23 & -- \\
\hline $\begin{array}{l}\text { Moringa } \\
\text { Oleifera }\end{array}$ & 21 & -- & 16 & 23 & 21 & 21 & -- & 22 & 23 & 25 & 18 & 21 \\
\hline $\begin{array}{l}\text { Psidium } \\
\text { guajava }\end{array}$ & 20 & 15 & -- & -- & 27 & 18 & -- & 16 & -- & 20 & 13 & 12 \\
\hline $\begin{array}{l}\text { Saraca } \\
\text { indica }\end{array}$ & -- & -- & -- & 18 & -- & 12 & -- & 20 & 14 & 25 & 28 & 23 \\
\hline $\begin{array}{l}\text { Tamarindus } \\
\text { indicum }\end{array}$ & 14 & 19 & 12 & 12 & 18 & 14 & 15 & 15 & 17 & 23 & 23 & 22 \\
\hline $\begin{array}{l}\text { Thuja } \\
\text { compacta }\end{array}$ & -- & -- & 20 & 20 & 11 & 15 & 13 & -- & -- & 13 & 16 & 11 \\
\hline $\begin{array}{l}\text { Vitex } \\
\text { negundo }\end{array}$ & 26 & -- & 16 & 23 & -- & -- & -- & -- & 13 & 19 & 16 & 18 \\
\hline
\end{tabular}


Most studies show that crude extract of leaves of Acacia arabica are active against several types of cariogenic bacteria found in human oral cavity (Akpata and Akinremisi, 1997). In present study, extract of leaves of Acacia arabica found to be inhibited against both Gram-positive as well as some Gram-negative organisms but Escherichia coli, salmonella typhi, Klebsiella pneumoniae and Pseudomonas aeroginosa were found resistant. Aegle marmelos was found very effective against all Gram negative organisms but all Gram positive organisms were found resistant. It shows good inhibitory effect against Bacillus cereus, B.subtilis, S.aereus in petroleum ether (Shukla and Mehta 2007). The methanol extracts of Aegle marmelos also shows great effect against both Gram positive and Gram negative organisms (Suresh et al., 2009). Staphylococcus strains are of great concern as several of its strains are drug resistant (Lechner 2004). The crude extracts of leaves of Ailanthus excelsa showed inhibitory effect against all Gram negative organisms and Staphylococcus aureus. The chloroform extract of this plant shows a effective result against bacteria and fungi like Aspergillus niger, A. fumigatus, Penicillium frequentence, $P$. notatum and Botrytis cinerea (Joshi et al., 2003). In the present study Saraca indica showed inhibition against Klebsiella pneumoniae, Proteus mirabilis and all Gram-positive organisms. The petroleum ether extracts of Saraca indica leaves show great effects against larvae of Culex quinquefasciatus with LC50 values 228.9 and 291.5ppm (Mathew et al., 2008). Callistemom lanceolantus was most effective against Pseudomonas aeroginosa and Bacillus cereus. Casurina equisitifolia was effective against all most all organisms except Salmonella typhi and Pseudomonas aeroginosa. Catharanthus roseus was effective against both Gram-positive and Gram-negative organisms except Salmonella typhi, Pseudomonas aeruginosa,
Staphylococcus aureus, Staphylococcus epidermis and Bacillus cereus. Grevellia robusta showed activity against Gramnegative and Gram-positive organisms except Salmonella typhi, Proteus vulgaris, Staphylococcus aureus and Staphylococcus epidermis. Kalanchoe pinnata inhibited all except Staphylococcus aureus, Staphylococcus epidermis and Bacillus megaterium.

\section{References}

Akpata, E.S. and Akinremisi, E.O. 1997. Antimicrobial activity of extracts of some African chewing sticks. Oral Surg., oral Med., Oral Pathol. 44: 717725.

Akpata, E.S., Almas, K. and Bagieh, N.H. 1997. In vitro antimicrobial effects of extracts of freshly cut and one month of old miswak. Biomedical Letters. 56: 145-149.

Alam, M.T., Karim, M.M. and Khan, S.N. 2009. Antibacterial activity of different organic extracts of Achyranthes Aspera and Cassia Alata. J. of Scientific Research. 1(2): 393-398.

Bereksi M.S., Hassaïne H, Bekhechi C, Abdelouahid D E. 2018. Evaluation of Antibacterial Activity of some Medicinal Plants Extracts Commonly Used in Algerian Traditional Medicine against some Pathogenic Bacteria. Pharmacogn J; 10(3):507-512

Cowan MM.1999. Plant Products as Antimicrobial Agents. Clin Microbiol Rev.;12(4):564-82.

Dulger and Gonuz, A. 2004. Antimicrobial activity of some Turkish medicinal plants. Pakistan J. of Biological Sciences. 7(9): 1559-1562.

Ellof, J.N. 1998. Extractant should be used for the screening and isolation of antimicrobial components from plants. Etanopharmocol. 60: 1-6. 
Gislene, G.F.N., Locatelli, J., Frietas, P.C. and Silva, G.L. 2000. Braz. J. Microbial. 31: 1-6.

Joshi, B.C., Pandey, A., Chaurasia, L. and Pal, M. 2003. Antifungal activities of stem bark of Ailanthus excels. Fitoterapia. 74(7-8): 689-691

KakadS.L., Tungikar VV, Dhembare A. J. 2015. Evaluation of antibacterial activity of plant extracts against bacterial pathogen. Pelagia Research Library Der Pharmacia Sinica, 6(1):1-5

Kusumto, I.T., Nakabayashi, T.K.H. 1995. Screening of various plant extracts used in Ayurvedic medicine for inhibitory effects on human immunodeficiency type1(HIV-1) protease. Phytotherapy Res. 9:180-184.

Lechner, D., Stavri, M., Oluwatuyi, M., Pereda-Miranda, R. and Gibbons, S. 2004. The anti-staphylococcal activity of Angelica dahurica (Bai Zhi). Phytochemistry. 65: 331-335.

Mathew, N., Anitha, M.G., Bala, T.S.L.,
Sivakumar, S.M., Narmadha, R. and Kalyanasundram, M. 2008. Larvicidal activity of Saraca indica, Nyctanthas arbortristis and Clitoria ternatea extracts against three mosquito vector species. J. of Parisitology Research. 104: 1017-1025.

Mukherjee, P.K. 2005. Quality control herbal drugs-An approach to evaluation of botanicals. 2 .

Shah, N.J. and Jadhav, B.L. Antimicrobial screening of two mangrove plants Salvadora persica and Avicenia officinalis occurring along Mumbai coast. Proc. National Conference on human health and Nutrition: A Biotechnological approach.

Shukla, S. and Mehta, A. 2007. Antibacterial activity of Aegle marmelos.

Suresh, K., Senthi, K.P. and Keyan, K. 2009. Antimicrobial activity of Aegle marmelos against clinical pathogens. $J$. of Phytology. 1: 5

\section{How to cite this article:}

Chandekar, C.J. 2018. Evaluation of Antibacterial Activity of Plant Extracts on Antibiotic Resistant Bacteria. Int.J.Curr.Microbiol.App.Sci. 7(12): 1164-1170. doi: https://doi.org/10.20546/ijcmas.2018.712.144 